\title{
D-Amino-acid oxidase gene from Rhodotorula gracilis (Rhodosporidium toruloides) ATCC 26217
}

\author{
Jorge Alonso, ${ }^{1}$ José L. Barredo, ${ }^{2}$ Bruno Díez, ${ }^{2}$ Encarnación Mellado, ${ }^{2}$ \\ Francisco Salto, ${ }^{2}$ José L. García ${ }^{1}$ and Estrella Cortés ${ }^{1}$
}

Author for correspondence: José L. García. Tel: +3415611800. Fax: + 3415627518. e-mail: CIBG160@FRESNO.CSIC.ES

1 Department of Molecular Microbiology, Centro de Investigaciones Biológicas (CSIC), Velázquez 144, 28006 Madrid, Spain

2 Laboratorio de Ingeniería Genética, Antibióticos SA, León, Spain

\begin{abstract}
The complete nucleotide sequence of the DAO1 gene encoding D-amino-acid oxidase (DAAO) in the yeast Rhodotorula gracilis (Rhodosporidium toruloides) ATCC 26217 has been determined. The primary structure of DAAO was deduced from the nucleotide sequence of a CDNA clone that covered the entire amino acid coding sequence. Comparison of CDNA and genomic sequences of DAO1 revealed the presence of five introns. Because this is the first gene of strain ATCC 26217 that has been cloned so far, the nucleotide sequences of these introns were compared to those from other fungi. Upstream of the structural gene there was a stretch of C + T-rich DNA similar to that found in the promoter region of a number of yeast genes. The cDNA gene, which encoded a protein of 368 amino acids (molecular mass $40 \mathrm{kDa}$ ), was overexpressed in Escherichia coli under the control of the strong lipoprotein promoter. Interestingly, a significant fraction (13-62\%) of the total DAAO activity was recovered in its apoenzyme form, the percentage depending on the culture conditions. This fact allowed a rapid purification of the recombinant DAAO by affinity chromatography. The high level of expression achieved in $E_{\text {. coli and }}$ the possibility of modifying its catalytic properties by protein engineering provide a new model for the study of this enzyme.
\end{abstract}

Keywords: D-amino-acid oxidase, Rhodotorula gracilis, gene expression, yeast, Escherichia coli

\section{INTRODUCTION}

D-Amino-acid oxidase [DAAO; D-amino-acid:oxygen oxidoreductase (deaminating); EC 1.4.3.3] is a flavoenzyme containing FAD as the prosthetic group. It catalyses stereospecifically the oxidative deamination of $\mathrm{D}$-amino acids, producing the corresponding 2-oxoacid and ammonia with a concomitant reduction of molecular oxygen to hydrogen peroxide. DAAOs have been reported in a wide variety of organisms, including animals and micro-organisms (Curti et al., 1992). Although it was first detected 60 years ago in pig kidney, and is considered as a marker enzyme for peroxisomes, the physiological role of the enzymes remains obscure (Angermüller, 1989).

\section{Abbreviation: DAAO, D-amino-acid oxidase.}

The GenBank accession number for the sequence reported in this paper is 271657.
Although some DAO1 genes have been cloned and sequenced (Fukui et al., 1987; Furuya \& Matsuda, 1993; Isogai et al., 1990; Jacobs et al., 1987; Momoi et al., 1988, 1990; Tada et al., 1990), only four enzymes have been isolated to homogeneity, i.e. those from pig kidney (Jacobs et al., 1987), Rhodotorula gracilis (Rhodosporidium toruloides) (Pilone et al., 1987), Trigonopsis variabilis (Pollegioni et al., 1993) and Fusarium solani (Isogai et al., 1990). More recently, the primary structure of the DAAO from $R$. gracilis has been determined by Edman degradation (Faotto et al., 1995). In addition, during the preparation of this manuscript the cDNA sequence encoding the DAAO from $R$. gracilis has been submitted to GenBank (U60066).

DAAO has considerable biotechnological importance because it is used for the deamination of cephalosporin $\mathrm{C}$ on the two-step enzymic route to 7-aminocephalosporanic acid (Fig. 1). This compound is the starting material for producing several cephem antibiotics 


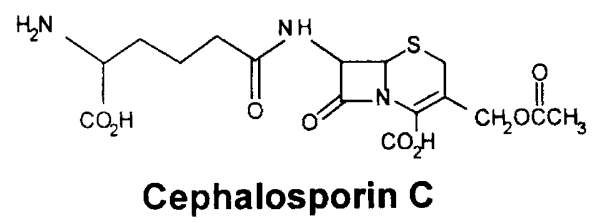

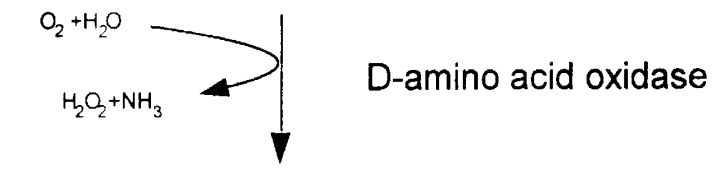<smiles>CC(=O)CC1=C(O)C2SCC(NC(=O)CCCC(=O)C(=O)O)C2C1=O</smiles>

Ketoadipyl-7-ACA<smiles>CC(C)(C)OC(=O)C(C)(C)C</smiles><smiles>CC(=O)CC1=C(C=O)C(=O)N2SC1C(NC(=O)CCCC=O)C2=O</smiles>

Glutaryl-7-ACA

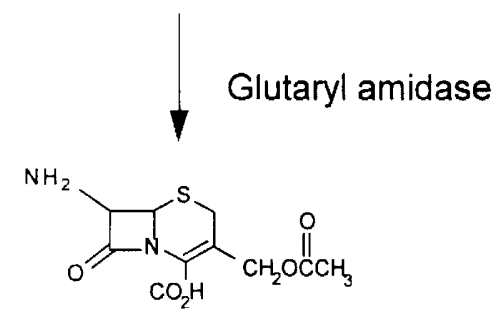

7-ACA

Fig. 1. Two-step enzymic synthesis of 7-aminocephalosporanic acid (7-ACA) from cephalosporin $C$. Cephalosporin $C$ is transformed to $7-\beta$-carboxy-5-oxopentanamido-cephalosporanic acid (ketoadipyl-7-ACA) by DAAO, which results in glutaryl-7ACA after treatment with hydrogen peroxide. Finally, glutaryl7-ACA is hydrolysed to 7-ACA by glutaryl amidase.

(Furuya \& Matsuda, 1993). Because the mammalian enzyme is not suitable for biotechnological applications, much effort has been directed towards the preparation of yeast enzymes. In this sense, the DAAO enzyme from the archetypal oleaginous yeast $R$. gracilis has been extensively characterized (Faotto et al., 1995; Gadda et al., 1994; Pilone et al., 1987; Pollegioni et al., 1995). This enzyme is a dimer of molecular mass $79000 \mathrm{Da}$ that is produced through induction by D-alanine (Pilone $e t$ al., 1987; Perotti et al., 1991). It has crucial properties that are different from those of other known DAAOs, such as the tightness of FAD binding and a high turnover number with various substrates that render it a suitable biocatalyst for industrial exploitation (Pollegioni et al., 1995). However, the major drawback of using this enzyme on an industrial scale has been the low level of activity in the yeast strain. Because of the requirement of a highly productive process, our efforts were directed toward the cloning and expression in Escherichia coli of the DAO1 gene from $R$. gracilis.

This paper deals with the characterization of the DAO1 gene from $R$. gracilis. We present here the nucleotide sequence of the genomic gene and its corresponding cDNA as well as its overproduction in E. coli.

\section{METHODS}

Bacterial strains, plasmids and media. $R$. gracilis ATCC 26217 was provided by the Colección Española de Cultivos Tipo. E. coli strains used were DH5 $\alpha$ (Sambrook et al., 1989), NM538 (Promega) and NM539 (Promega). Plasmids pINIIIA3 (Inouye \& Inouye, 1985) and $\mathrm{pBC} \mathrm{KS}(+)$ (Stratagene) were used for cloning and sequencing. The phage $\lambda \mathrm{GEM}-12$ (Promega) was used for the construction of the genomic library. $R$. gracilis was grown at $\mathrm{pH} 5.6$ in a basal medium supplemented with $30 \mathrm{mM}$ D-alanine for $24 \mathrm{~h}$ at $30^{\circ} \mathrm{C}$ with shaking (Perotti et al., 1991). E. coli cells were cultured in LB broth (Sambrook et al., 1989) at 25 or $37^{\circ} \mathrm{C}$ with shaking. Ampicillin $\left(100 \mu \mathrm{g} \mathrm{m}^{-1}\right)$ or chloramphenicol $\left(34 \mu \mathrm{g} \mathrm{ml}^{-1}\right)$ was added to the culture medium when required.

Molecular cloning and sequencing procedures. Plasmid DNA was isolated by the alkaline extraction procedure or by $\mathrm{CsCl}$-ethidium bromide equilibrium density-gradient centrifugation (Sambrook et al., 1989). The selected plasmids were sequenced by the dideoxy-mediated chain-termination method using double-stranded plasmids as templates and universal or synthetic oligonucleotides as primers. $R$. gracilis chromosomal DNA was isolated by the method of Sherman et al. (1986). Southern blot analysis was carried out as described by Sambrook et al. (1989). Labelling of the DNA probe was performed using the polar PLFX chemiluminescent blotting kit (Millipore). Competent cells for transformation were prepared using the rubidium chloride treatment (Sambrook et al., 1989). Oligonucleotides RG1 [5'-GACCT(C/G)CC(C/G)GAGGACGT $(\mathrm{C} / \mathrm{T} / \mathrm{G})(\mathrm{T} / \mathrm{A})(\mathrm{C} / \mathrm{G})(\mathrm{T} / \mathrm{A})(\mathrm{C} / \mathrm{G})(\mathrm{G} / \mathrm{C}) \mathrm{CAG}-$ AC-3'], RG2 [5'-GC(C/G)GG(G/C/T)CG(A/C/G)AG(G/A/C)CC(G/A/C)ACGTTGTG-3'], RT1 (5'-GGAGGAATTCATATGCACTCTCAGAAGCGCGTCG-3') and RT2 $\left(5^{\prime}\right.$. CCATCGATAAGCTTACAACTTCGACTCCCGCGCCGC-3') were used for cDNA synthesis or PCR amplifications. Total RNA was extracted as previously described by Köhrer \& Domdey (1991). cDNA was prepared using avian myeloblastosis virus (AMV) reverse transcriptase (Promega) according to the recommendations of the supplier.

In brief, annealing took place over $5 \mathrm{~min}$ at $70^{\circ} \mathrm{C}$ followed by $5 \mathrm{~min}$ at $25^{\circ} \mathrm{C}$ in a total volume of $10 \mu \mathrm{l}$ containing 20 units rRNasin (Promega), $7.5 \mu \mathrm{g}$ total RNA and $2 \mu \mathrm{M}$ primer RT2. Extension occurred over $90 \mathrm{~min}$ at $42^{\circ} \mathrm{C}$ followed by $5 \mathrm{~min}$ denaturation at $95^{\circ} \mathrm{C}$ in a total volume of $40 \mu \mathrm{l}$ of the buffer recommended by the manufacturer containing the annealing solution, 20 units rRNasin, $1 \mathrm{mM}$ of each dNTP and 40 units AMV reverse transcriptase. Amplification of cDNA with primers RT1 and RT2 was achieved with 30 cycles of $1 \mathrm{~min}$ denaturation at $95^{\circ} \mathrm{C}, 2 \mathrm{~min}$ annealing at $55^{\circ} \mathrm{C}$ and $2 \mathrm{~min}$ of 
polymerase extension at $72{ }^{\circ} \mathrm{C}$, using $2.5 \mu \mathrm{l}$ cDNA solution, 2.5 units Taq polymerase (Perkin Elmer Cetus), $1 \mu \mathrm{M}$ of each synthetic oligonucleotide primer, $250 \mu \mathrm{M}$ of each dNTP, $13 \%$ glycerol and $2 \mathrm{mM} \mathrm{MgCl}_{2}$, in $100 \mu$ lof the buffer recommended by the manufacturer. Amplification with primers RG1 and RG2 was achieved with 5 cycles of 1 min denaturation at $98^{\circ} \mathrm{C}, 2 \mathrm{~min}$ annealing at $55^{\circ} \mathrm{C}$ and $2.5 \mathrm{~min}$ of polymerase extension at $72^{\circ} \mathrm{C}$, followed by 30 cycles of $1 \mathrm{~min}$ denaturation at $95^{\circ} \mathrm{C}, 2 \mathrm{~min}$ annealing at $55^{\circ} \mathrm{C}$ and $2.5 \mathrm{~min}$ of polymerase extension at $72^{\circ} \mathrm{C}$, using $1 \mu \mathrm{g}$ chromosomal DNA, 2.5 units Taq polymerase (Perkin Elmer Cetus), $0.25 \mu \mathrm{M}$ of each synthetic oligonucleotide primer, $250 \mu \mathrm{M}$ of each dNTP, $13 \%$ glycerol and $2 \mathrm{mM} \mathrm{MgCl}{ }_{2}$, in $100 \mu \mathrm{l}$ of the buffer recommended by the manufacturer. PCR amplifications were done using Gene-ATAQ equipment (Pharmacia). PCR fragments were purified using $\beta$-agarase according to the recommendations of the supplier (New England Biolabs).

Construction of a genomic library. Total DNA of $R$. gracilis was partially digested with Sau3AI and fragments of about $20 \mathrm{~kb}$ were isolated in a sucrose gradient $(10-40 \%)$. These fragments were ligated to purified $\lambda$ GEM-12 (Promega) arms, Bam $\mathrm{HI}$ digested, and the ligation mixture was packaged using the Packagene System (Promega). The complete genomic library (60000 p.f.u.) was transferred to nitrocellulose filters (BA85, 0.45 $\mu \mathrm{m}$; Schleicher \& Schuell) and hybridized using standard methods (Sambrook et al., 1989).

DAAO activity assay. The standard assay was done using a Shimadzu UV-260 spectrophotometer to follow the increase in $A_{252}$ using $25 \mathrm{mM}$ D-phenylglycine as substrate (Fonda \& Anderson, 1967). Incubation was carried out at $30^{\circ} \mathrm{C}$ in $50 \mathrm{mM}$ sodium phosphate buffer, $\mathrm{pH} 8.0$, containing $1 \mu \mathrm{M}$ FAD. One unit of the enzyme activity was defined as the amount of enzyme transforming $1 \mu \mathrm{mol}$ substrate $\mathrm{min}^{-1}$. To compare the enzyme activities obtained by this method with previous data reported in the literature, the DAAO activity was occasionally assayed by polarography at $37^{\circ} \mathrm{C}$ with a Hansatech oxygen electrode using D-alanine as substrate (Pilone et al., 1987). In this case, one unit of activity corresponds to the uptake of $1 \mu \mathrm{mol}$ oxygen $\mathrm{min}^{-1}$. Note that the values determined with the standard assay were about 10-14-fold lower than that determined polarographically using D-alanine as substrate. The percentage of the holoenzyme form contained in the cell extract was determined by comparing the DAAO activity in the presence and absence of exogenous FAD. The protein concentration was determined by the method of Bradford (1976).

Purification of recombinant DAAO. Cells of E. coli DH5 $\alpha$ (pCDAAO20) were grown at $25^{\circ} \mathrm{C}$ with shaking (250 r.p.m.) for $12 \mathrm{~h}$ in a 21 flask containing $200 \mathrm{ml} \mathrm{LB}$ medium plus ampicillin $\left(100 \mu \mathrm{g} \mathrm{ml}^{-1}\right)$ in a shaking incubator (New Brunswick Scientific). Approximately $50 \%$ of the DAAO produced under these culture conditions is recovered in the apoenzyme form (Table 1, see below). Cells were collected by centrifugation, washed and resuspended in $20 \mathrm{ml}$ sodium phosphate buffer $(20 \mathrm{mM}, \mathrm{pH} 8.0)$ containing $20 \%$ glycerol, $5 \mathrm{mM} 2-$ mercaptoethanol and $2 \mathrm{mM}$ EDTA (buffer A), before disruption by passage through a French press (Aminco) operated at a pressure of 20000 p.s.i. (138 MPa). The cell debris was removed by centrifugation at 18000 r.p.m. for $20 \mathrm{~min}$ in an SS34 rotor (Sorvall). The clear supernatant fluid $[0.5 \mathrm{U} / \mathrm{mg}$ protein $)^{-1}$ ] was loaded in a DEAE-cellulose column $(6 \times$ $2.5 \mathrm{~cm}$ ) equilibrated and eluted with buffer $A$. The active fractions $\left.[50 \mathrm{ml}, 1.3 \mathrm{U} \text { (mg protein })^{-1}\right]$ were combined and applied to a Cibacron Blue $3 \mathrm{GA}$-Sepharose column $(4 \times 1 \mathrm{~cm})$ equilibrated with buffer $\mathrm{A}$. The column was washed with $30 \mathrm{ml}$ sodium phosphate buffer $(1 \mathrm{M}, \mathrm{pH} 8.0)$. This wash fraction contained the holoenzyme form of DAAO and many contaminant proteins that were not retained in the matrix. The DAAO retained on the column (apoenzyme form) was eluted in $10 \mathrm{ml}$ sodium phosphate buffer $(20 \mathrm{mM}, \mathrm{pH} 8 \cdot 0)$ containing $20 \%$ glycerol, $5 \mathrm{mM}$ 2-mercaptoethanol, $2 \mathrm{mM}$ EDTA and $50 \mu \mathrm{M}$ FAD. Note that because of the presence of FAD in the elution buffer, the purified DAAO was recovered in the holoenzyme form. The purified enzyme showed a specific activity of $13 \mathrm{U}$ (mg protein) $)^{-1}$ on D-phenylglycine using the standard assay and $194 \mathrm{U}$ (mg protein $)^{-1}$ on $\mathrm{D}$ alanine when it was determined by the polarographic method.

Western blot analysis. Western blot analysis was performed according to the procedure previously described by SánchezPuelles et al. (1992). Rabbit antibodies against DAAO of $R$. gracilis were prepared as described by Sánchez-Puelles $e t$ al. (1992), using the purified yeast enzyme supplied by Dr M. P. Castillón (Complutensian University of Madrid).

\section{RESULTS AND DISCUSSION}

\section{Cloning of the genomic DAO1 gene of $R$. gracilis}

A $1 \mathrm{~kb}$ fragment containing a segment of the DAO1 gene of $R$. gracilis was isolated by PCR using the degenerate primers RG1 and RG2. These primers were designed according to the sequences of the peptides DLPEDVSSQT and HNVGLRPA, which had already been determined as part of the DAAO enzyme (Gadda et al., 1994), before the complete amino acid sequence was available (Faotto et al., 1995). The resulting PCR fragment was cloned into the EcoRV site of the vector $\mathrm{pBC} \mathrm{KS}(+)$, producing the recombinant plasmid pPCR20. The high similarity of the deduced amino acid sequence encoded by this fragment with that of other DAAOs strongly suggested that it corresponded to the DAO1 gene of $R$. gracilis. Thereafter, the $1 \mathrm{~kb}$ HindIII-EcoRI fragment of pPCR20 was used as a probe to screen a Sau3AI genomic library of $R$. gracilis constructed in the $B a m \mathrm{HI}$-digested bacteriophage $\lambda$ GEM-12. Sixteen of 54 positive phages were isolated and analysed by Southern blotting, which showed that all of them contained the putative DAO1 gene in $8.5 \mathrm{~kb}$ EcoRI and $3.5 \mathrm{~kb}$ HindIII fragments. These fragments were subcloned in both orientations into the vector pBC KS $(+)$, digested with HindIII or EcoRI, producing the plasmids pALR90 and pALR91 (3.5 kb HindIII fragment) and pALR92 and pALR93 (8.5 kb EcoRI fragment). The complete genomic sequence of the DAO1 gene was determined using these plasmids as DNA templates and specific oligonucleotides as primers (Fig. 2). A preliminary analysis of this sequence revealed the existence of several truncated open reading frames as well as different putative lariat sequences, suggesting that the gene might contain a large number of introns.

\section{Cloning and sequencing of the cDNA encoding the DAAO of $R$. gracilis}

Although the analysis of the genomic DAO1 gene did not allow us to determine precisely the amino acid sequence of the protein, its comparison to other DAAOs provided an excellent clue about the regions that might encode the $\mathrm{N}$ - and C-terminal segments of the protein. 


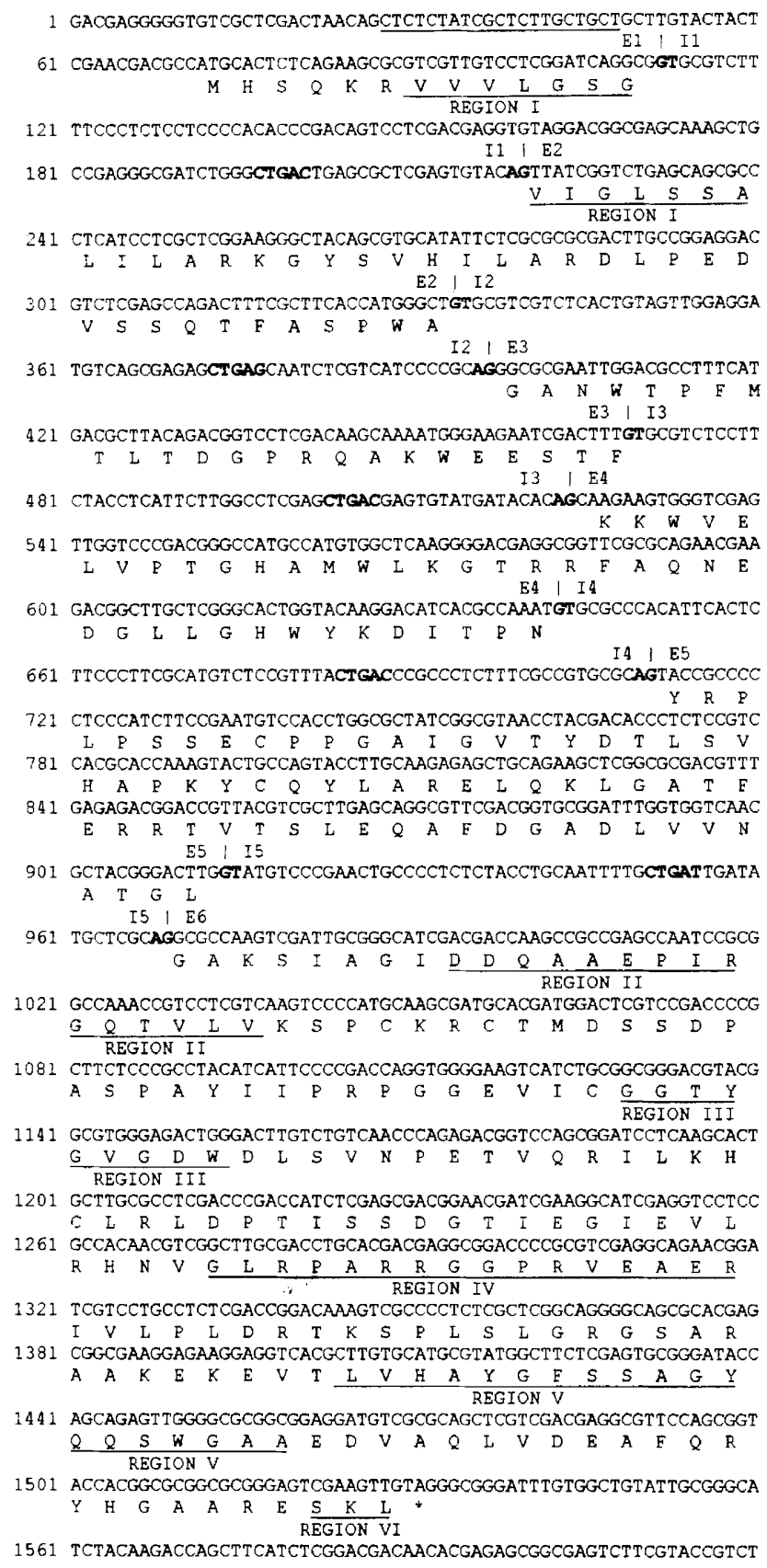

Fig. 2. Nucleotide and deduced amino acid sequence of the genomic clone for the $R$. gracilis DAO1 gene. The introns (11-15) and exons (E1-E6) are indicated. The sequences of the lariats and the $5^{\prime}$ - and $3^{\prime}$-ends of the introns are shown in bold letters. The $C+T$-rich region is underlined. Regions $I-V I$ indicate the amino acids that are conserved in all DAAOs (Faotto et al, 1995).

To clone the cDNA of the DAO1 gene, the mRNA complementary strand was prepared using the oligonucleotide RT2 corresponding to the 3 '-end of the gene. Then, a mixture of oligonucleotides RT1 and RT2 was used to amplify the resulting complementary strand by PCR. The RT1 primer also contains the sequence GGAGG (ribosome-binding site) to facilitate the translation of the $D A O 1$ gene in $E$. coli. The resulting $1 \cdot 1 \mathrm{~kb}$

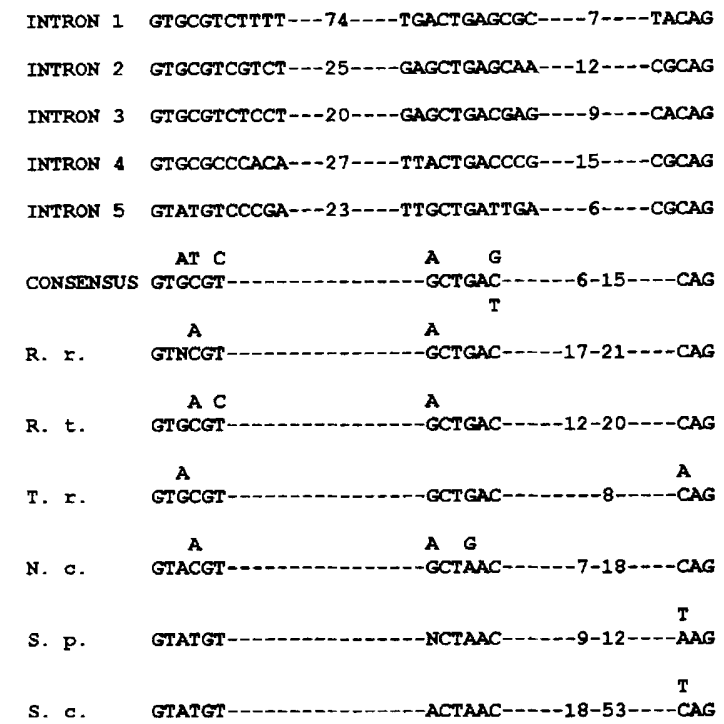

Fig. 3. Analysis of the $D A O 1$ gene introns. The intron sequences of R. rubra (R. r), Rhodosp. toruloides IFO 0559 (R. t.), Trich. reesei (T. r.), Neurospora crassa ( $N$. c.), Schizosaccharomyces pombe (S. p.) and Saccharomyces cerevisiae (S. C.) have been published (Anson et al., 1987; Filpula et al., 1988; Gallwitz et al., 1987). Dashes represent non-consensus nucleotides.

fragment was subcloned into the EcoRV site of the vector $\mathrm{pBC} K S(+)$, producing the plasmids pCDAAO10 and $\mathrm{pCDAAO} 11$.

The sequence of the cDNA insert of pCDAAO10 revealed the presence of five introns within the genomic DAO1 gene (Fig. 2). Although the existence of introns has been described in yeast, they are very much the exception, relatively short and mainly located in the $5^{\prime}$ end of the coding sequence (Gallwitz et al., 1987). Hence, the high number of introns detected in the DAO1 gene of $R$. gracilis appears to be one of these rare exceptions. Because this is the first genomic gene of $R$. gracilis ATCC 26217 that has been sequenced so far, no data on the intron structure in this yeast are available for comparison. Nevertheless, the genomic PAL (phenylalanine ammonia-lyase) genes of the related microorganisms Rhodotorula rubra and Rhodosp. toruloides IFO 0559 contain five and six introns, respectively (Anson et al., 1987; Filpula et al., 1988). In common with a number of genes from yeast and filamentous fungi, the DAO1 introns were relatively small with sizes ranging from 56 to $108 \mathrm{bp}$. All five introns contained the nucleotides CAG at their 3 '-ends, demonstrating perfect agreement with the consensus intron acceptor sequence observed in eukaryotic genes. The sequences at the $5^{\prime}$ end also exhibited a good overall agreement with the consensus donor sequences (Fig. 3). The internal intron sequence needed for the splicing mechanism (lariat formation) was also conserved in the case of the DAO1 gene (Fig. 3). However, note that the consensus sequence is more similar to that of R. rubra, Rhodosp. toruloides IFO 0559 or Trichoderma reesei than to that of other yeasts. 
Table 1. DAAO activity of cell extracts of $E$. coli recombinants cultured under different conditions

Recombinant E. coli DH5 $\alpha$ cells were cultured for $12 \mathrm{~h}$ at 25 or $37^{\circ} \mathrm{C}$ with shaking $(250$ r.p.m.) in $100 \mathrm{ml}$ flasks containing $10 \mathrm{ml}$ (high aeration) or $50 \mathrm{ml}$ (low aeration) LB medium plus ampicillin or chloramphenicol. Flasks were inoculated with a final ratio of $1 / 10$ of an overnight culture grown at 25 or $37^{\circ} \mathrm{C}$. Enzyme activities [U (mg protein $)^{-1}$ ] were determined with the standard assay. Values in parentheses indicate the percentage of the holoenzyme form of DAAO present in the cell extracts. This value was calculated by comparing the enzyme activity in the absence and presence of exogenous FAD $(1 \mu \mathrm{M})$.

\begin{tabular}{|c|c|c|c|c|}
\hline \multirow[t]{3}{*}{ Plasmid } & \multicolumn{4}{|c|}{ Aeration at: } \\
\hline & \multicolumn{2}{|c|}{$25^{\circ} \mathrm{C}$} & \multicolumn{2}{|c|}{$37^{\circ} \mathrm{C}$} \\
\hline & High & Low & High & Low \\
\hline pCDAAO10 & $0.09(47 \%)$ & $0 \cdot 14(70 \%)$ & $0.01(38 \%)$ & $0.26(59 \%)$ \\
\hline pCDAAO20 & $0.24(66 \%)$ & $0.31(87 \%)$ & $0.03(51 \%)$ & $0.60(74 \%)$ \\
\hline
\end{tabular}

The analysis of the $5^{\prime}$ non-coding sequence of the DAO1 gene revealed that there is a $\mathrm{C}+\mathrm{T}$-rich region just upstream of the ATG start codon (Fig. 2). Although the functional significance of these sequences remains to be determined, equivalent $\mathrm{C}+\mathrm{T}$-rich regions have been observed in a number of highly expressed genes, including the PAL genes of $R$. rubra and Rhodosp. toruloides IFO 0559 (Anson et al., 1987; Filpula et al., 1988). We have not been able to identify a consensus TATA box; however, the existence of a CGAA box downstream from the $\mathrm{C}+\mathrm{T}$-rich block is remarkable because, in efficiently expressed yeast genes, transcription start sites are often located in this sequence (Brown \& Lithgow, 1987). Moreover, the $\mathrm{C}+\mathrm{T}$-rich regions are located immediately upstream of the transcription start point, particularly in highly expressed genes lacking apparent TATA boxes.

The amino acid sequence of DAAO from $R$. gracilis deduced from the cDNA and genomic clones revealed that the enzyme contains 368 amino acid residues $(40 \mathrm{kDa})$. This sequence was identical to that previously determined by automated Edman degradation (Faotto $e t$ al., 1995). The nucleotide sequence of the cDNA was almost identical to that reported in GenBank under the accession number U60066, because only two differences in the third nucleotide of the codons for $\mathrm{Ser}_{3}$ (TCT for TCG) and Gly ${ }_{199}$ (GGC for GGG) were observed. As in other fungal genes, the codon utilization is biased and those codons ending in $\mathrm{A}$ are used infrequently. This phenomenon does not seem to be a consequence of the high $\mathrm{G}+\mathrm{C}$ content as a similar selection for codons ending in $\mathrm{T}$ is not observed. The deduced amino acid sequence showed a remarkable similarity to the sequences of other DAAOs (Faotto et al., 1995). The six highly conserved regions of the protein that have been postulated to play important roles in FAD binding (regions I and III), in active site topology (regions II, IV and $\mathrm{V}$ ) and in peroxisomal targeting (VI) are located in exons E1, E2 and E6 (Fig. 2) (Faotto et al., 1995). Note that the first intron of the $R$. gracilis DAO1 gene divides the consensus FAD-binding sequence, Gly-X-Gly-X-XGly, into two exons as occurs in the DAO1 gene of Trig. variabilis (Furuya \& Matsuda, 1993), whereas the other conserved regions of the enzyme are encoded by the last exon.

\section{Overexpression of the DAO1 gene in E. coli}

When DAAO production was analysed by the standard assay in the recombinant $E$. coli $\mathrm{DH} 5 \alpha$ cells harbouring plasmid pCDAAO10, a considerable enzyme activity was detected $\left.[0.26 \mathrm{U} \text { (mg protein })^{-1}\right]$ (Table 1). Nevertheless, because this plasmid expresses the DAO1 gene under the control of the lac promoter we tried to increase this production by subcloning the $\mathrm{Xba \textrm {I } - H i n \mathrm { dIII }}$ fragment of plasmid pCDAAO11 containing the DAO1 gene into the XbaI-HindIII-digested vector pINIII-A3 that carries the stronger $l p p$-lac promoter. As expected, we observed that clones carrying the resulting plasmid pCDAAO20 produced a higher amount of DAAO [0.60 U (mg protein) $\left.)^{-1}\right]$ (Table 1 ).

Analysis of DAO1 expression under several aeration conditions revealed that DAAO activity increased when cells were cultured with low aeration (Table 1). These results correlate with the intensities of the bands observed in SDS-PAGE as well as with the intensities of the signals detected by Western blot analysis (data not shown), suggesting that the activity matches the amount of protein produced by the cells. Although the reasons for such behaviour are still unknown, it can be argued that DAAO is probably lethal for the cells because it might drastically reduce the intracellular pool of $\mathrm{D}$ alanine, an essential component of the cell wall. In this sense, we have observed that some clones segregate into two different phenotypes, one exhibiting a normal colony morphology that is unproductive, and the other showing small, transparent and flat colonies firmly bound to the agar, producing a higher amount of 
DAAO. Hence, we propose that low aeration should favour DAAO production because a low availability of oxygen might reduce the enzyme activity and consequently its toxicity.

Taking into account that the lpp-lac promoter is inducible by IPTG, we tested the effect of this substance in DAAO production and observed that the addition of $5 \mathrm{mM}$ IPTG to the culture medium increased DAAO production $\left[0.99 \mathrm{U}(\mathrm{mg} \text { protein })^{-1}\right]$. To investigate the effect of $\mathrm{D}$-alanine on DAAO production, this compound was added to the culture medium at different concentrations showing the maximal effect at a concentration around $10 \mathrm{mM}\left[1 \cdot 14 \mathrm{U}\right.$ (mg protein) $\left.{ }^{-1}\right]$. Because the lpp-lac promoter is not inducible by $\mathrm{D}$-alanine, this effect cannot be ascribed to a direct increase of the DAO1 transcription. However, as pointed out above, the addition of exogenous $\mathrm{D}$-alanine should increase the internal pool of this critical amino acid, reducing the toxicity of DAAO activity and favouring the accumulation of the enzyme. Note that when the activity produced by $E$. coli DH $5 \alpha($ pCDAAO20), under these fermentation conditions, was determined by the polarographic method using D-alanine as substrate, we obtained a value of $15.6 \mathrm{U}$ (mg protein) $)^{-1}$. This production is about 20 -fold higher than the value of $0.6 \mathrm{U}$ (mg protein $)^{-1}$ reported for $R$. gracilis under optimal fermentation conditions (Pilone et al., 1989).

In contrast, we have observed that the DAAO extracted from the recombinant micro-organism requires the exogenous addition of FAD to reach maximum activity, suggesting that an important fraction of the enzyme is obtained in an inactive apoenzyme form. Depending on the culture conditions, between 13 and $62 \%$ of the total DAAO produced is recovered as apoenzyme (Table 1). In this context, it is worth noting that the amount of apoenzyme increased under high aeration conditions. Whether the presence of this inactive form reflects a low level of intracellular FAD that is insufficient to transform all the DAAO produced in E. coli into the holoenzyme form or whether it can be ascribed to folding/unfolding problems requires further investigation. Nevertheless, because the apoenzyme form of DAAO can be purified by affinity chromatography in Cibacron Blue-Sepharose, we were able to purify the recombinant DAAO from $E$. coli DH5 $\alpha$ (pCDAAO20) (Fig. 4). The purified enzyme showed a specific activity of $194 \mathrm{U}$ (mg protein $)^{-1}$ on Dalanine, which is similar to the value reported for the DAAO purified from $R$. gracilis (Pilone et al., 1989), suggesting that the enzyme produced in $E$. coli is identical to that produced in the yeast. In this sense, the biochemical and spectrophotometrical data obtained with the recombinant DAAO protein were indistinguishable from those obtained with the enzyme prepared from $R$. gracilis (data not shown).

The results presented here not only show for the first time the structure of a gene of the yeast $R$. gracilis ATCC 26217 but also demonstrate the possibility of overproducing its DAAO in a heterologous host. Consequently, these studies should facilitate the use of this

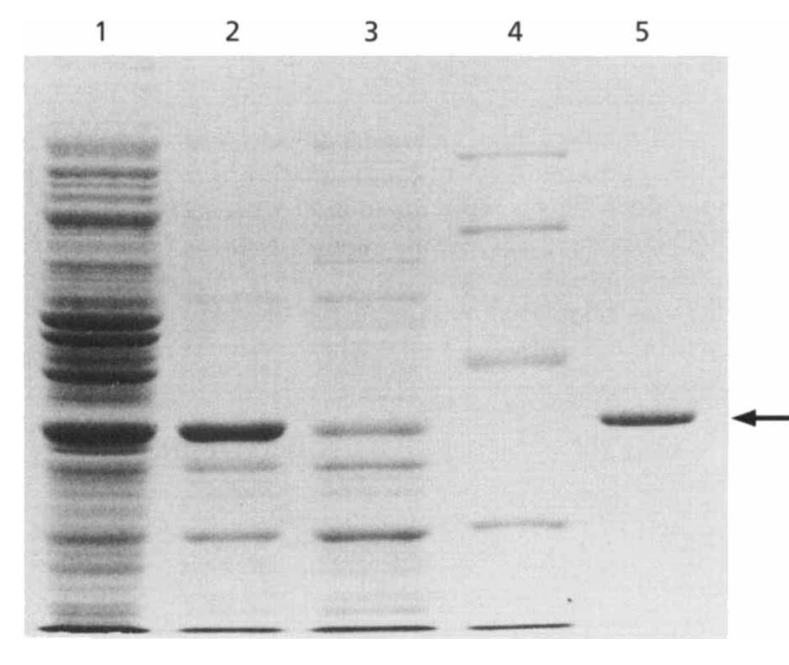

Fig. 4. SDS-PAGE of the purified recombinant DAAO. E. coli DH $5 \alpha\left(\right.$ pCDAAO20) cells were cultured at $25^{\circ} \mathrm{C}$ with a $1 / 10$ aeration ratio $(200 \mathrm{ml}$ LB medium in a 2 I flask). Lanes: 1 , cell extract; 2, proteins after DEAE-cellulose chromatography; 3, proteins eluted in $1 \mathrm{M}$ sodium phosphate buffer from Cibacron Blue-Sepharose; 4, molecular mass markers; 5, purified DAAO eluted in FAD-containing buffer from Cibacron Blue-Sepharose. The gel was stained with Coomassie blue.

enzyme on an industrial scale and open the possibility of analysing its structural and biochemical properties using genetic engineering approaches.

\section{ACKNOWLEDGEMENTS}

We thank P. García and E. Díaz for the critical reading of the manuscript and M. A. Moreno for helpful discussions. The authors are indebted to Dr E. Rial for helpful assistance in polarographic assays. The artwork of A. Hurtado and the technical assistance of $\mathrm{E}$. Cano and $\mathrm{M}$. Carrasco are gratefully acknowledged. We also thank Dr M. P. Castillón for providing a sample of purified DAAO. This work was supported by Antibióticos SA and a Concerted Action of the Centro de Desarrollo Tecnológico Industrial (CDTI).

\section{REFERENCES}

Angermüller, S. (1989). Peroxisomal oxidases: cytochemical localization and biological relevance. Prog Histochem Cytochem 20, 1-65.

Anson, J. G., Gilbert, H. J., Oram, J. D. \& Minton, N. P. (1987). Complete nucleotide sequence of the Rhodosporidium toruloides gene coding for phenylalanine ammonia-lyase. Gene 58, 189-199.

Bradford, M. M. (1976). A rapid and sensitive method for the quantitation of microgram quantities of protein utilizing the principle of protein-dye binding. Anal Biochem 72, 248-254.

Brown, A. J. P. \& Lithgow, G. (1987). The structure and expression of nuclear genes in Saccharomyces cerevisiae. In Gene Structure in Eukaryotic Microbes (Special Publication of the Society for General Microbiology no. 22), pp. 1-26. Edited by J. R. Kinghorn. Oxford: IRL Press.

Curti, B., Ronchi, S. \& Pilone, S. M. (1992). D- and L-amino acid oxidases. In Chemistry and Biochemistry of Flavoenzymes, vol. III, pp. 69-94. Edited by F. Muller. Boca Raton, FL: CRC Press. 
Faotto, L., Pollegioni, L., Ceciliani, F., Ronchi, S. \& Pilone, M. S. (1995). The primary structure of $\mathrm{D}$-amino acid oxidase from Rhodotorula gracilis. Biotechnol Lett 17, 193-198.

Filpula, D., Vaslet, C. A., Levy, A., Sykes, A. \& Strausberg, R. (1988). Nucleotide sequence of gene for phenylalanine ammonialyase from Rhodotorula rubra. Nucleic Acids Res 16, 11381.

Fonda, M. L. \& Anderson, B. M. (1967). D-Amino acid oxidase. Spectrophotometric studies. J Biol Chem 242, 3957-3962.

Fukui, K., Watanabe, F., Shibata, T. \& Miyake, Y. (1987). Molecular cloning and sequence analysis of cDNAs encoding porcine kidney D-amino acid oxidase. Biochemistry 26, 36123618.

Furuya, K. \& Matsuda, A. (1993). A transformant capable of producing D-amino acid oxidase. European Patent Application 583817A2.

Gadda, G., Negri, A. \& Pilone, M. S. (1994). Reaction of phenylglyoxal with arginine groups in D-amino-acid oxidase from Rhodotorula gracilis. J Biol Chem 269, 17809-17814.

Gallwitz, D., Halfter, H. \& Mertins, P. (1987). Splicing of mRNA precursors in yeast. In Gene Structure in Eukaryotic Microbes (Special Publication of the Society for General Microbiology no. 22), pp. 27-40. Edited by J. R. Kinghorn. Oxford: IRL Press.

Inouye, S. \& Inouye, M. (1985). Up-promoter mutations in the lpp gene of Escherichia coli. Nucleic Acids Res 13, 3101-3110.

Isogai, T., Ono, H., Ishitani, Y., Kojo, H., Ueda, Y. \& Kohsaka, M. (1990). Structure and expression of CDNA for D-amino acid oxidase active against cephalosporin C from Fusarium solani. J Biochem 108, 1063-1069.

Jacobs, P., Brockly, F., Massaer, M. \& 9 other authors (1987). Porcine D-amino acid oxidase: determination of the mRNA nucleotide sequence by the characterization of genomic and cDNA clones. Gene 59, 55-61.

Köhrer, K. \& Domdey, H. (1991). Preparation of high molecular weight RNA. Methods Enzymol 194, 398-405.

Momoi, K., Fukui, K., Watanabe, F. \& Miyake, Y. (1988). Molecular cloning and sequence analysis of cDNA encoding human kidney D-amino acid oxidase. FEBS Lett 238, 180-184.
Momoi, K., Fukui, K., Tada, M. \& Miyake, Y. (1990). Gene expression of $\mathrm{D}$-amino acid oxidase in rabbit kidney. $J$ Biochem 108, 406-413.

Perotti, M.-E., Pollegioni, L. \& Pilone, M. S. (1991). Expression of $\mathrm{D}$-amino acid oxidase in Rhodotorula gracilis under induction conditions: a biochemical and cytochemical study. Eur J Cell Biol 55, 104-113.

Pilone, S. M., Vanoni, M. A. \& Casalin, P. (1987). Purification and properties of D-amino acid oxidase, an inducible flavoenzyme from Rhodotorula gracilis. Biochim Biophys Acta 914, 136-142.

Pilone, S. M., Verga, R., Fretta, A. \& Hanozet, G. M. (1989). Induction of $\mathrm{D}$-amino-acid oxidase by $\mathrm{D}$-alanine in R hodotorula gracilis grown in defined medium. J Gen Microbiol 135, 593-600.

Pollegioni, L., Butò, S., Tischer, W., Ghisla, S. \& Pilone, M. S. (1993). Characterization of $\mathrm{D}$-amino acid oxidase from Trigonopsis variabilis. Biochem $\mathrm{Mol}$ Biol Int 31, 709-717.

Pollegioni, L., Ceciliani, F., Curti, B., Ronchi, S. \& Pilone, M. S. (1995). Studies on the structural and functional aspects of Rhodotorula gracilis $\mathrm{D}$-amino acid oxidase by limited trypsinolysis. Biochem J 310, 577-583.

Sambrook, J., Fritsch, E. F. \& Maniatis, T. (1989). Molecular Cloning: a Laboratory Manual, 2nd edn. Cold Spring Harbor, NY: Cold Spring Harbor Laboratory.

Sánchez-Puelles, J. M., Sanz, J. M., García, J. L. \& García, E. (1992). Immobilization and single-step purification of fusion proteins using DEAE-cellulose. Eur J Biochem 198, 153-159.

Sherman, F., Fink, G. R. \& Hicks, J. B. (1986). Laboratory Course for Methods in Yeast Genetics. Cold Spring Harbor, NY: Cold Spring Harbor Laboratory.

Tada, M., Fukui, K., Momoi, K. \& Miyake, Y. (1990). Cloning and expression of a cDNA encoding mouse kidney $\mathrm{D}$-amino acid oxidase. Gene $90,293-297$.

Received 16 September 1997; revised 26 November 1997; accepted 16 December 1997. 